\title{
Teknologi Ameliorasi dan Pemupukan Tanah Sub-Optimal Serta Hubungannya dengan Sifat Kimia Tanah dan Pertumbuhan Padi
} Galur Sikuneng

\author{
(Restoration Technology and Sub-Optimal Soil Fertilization and Its Relationship with \\ Soil Chemical Properties and Growth of Sikuneng Strain Rice)
}

\author{
Selly Nara Agustin ${ }^{1}$, Zuraida $^{1}$, Muyassir ${ }^{1 *}$ \\ ${ }^{1}$ Program Studi Ilmu Tanah, Fakultas Pertanian, Universitas Syiah Kuala \\ *Corresponding author: muyassir@unsyiah.ac.id
}

\begin{abstract}
Abstrak.Tanah suboptimal adalah tanah yang kehilangan kemampuannya untuk mendukung kegiatan fisiologis tumbuhan. Penelitian ini bertujuan untuk mendapatkan bahan amelioran dan dosis pupuk yang tepat sifat kimia tanah dan pertumbuhan padi galur sikuneng. Penelitian ini menggunakan metode eksperimen dimana perlakuan disusun dalam bentuk Rancangan Acak Kelompok pola Faktorial dan diulang sebanyak 3 kali. Faktor pertama bahan Amelioran yaitu Gipsum, Biochar danPIM-organik dan faktor kedua dosis pupuk Urea, SP36 danKCl. Hasil penelitian yang didapat adalahamelioran PIM-organik dapat meningkatkan $\mathrm{pH}$ dan pertumbuhanpadi galur sikuneng sedangkan perlakuan pupuk N:P:K 225:150:150 kg ha-1 dapat meningkatkanK-dd tanah suboptimal dan pertumbuhan padi galur sikuneng, serta terdapat interaksi amelioran dan pemupukan dalam meningkatkan Ptersedia dan jumlah anakan padi tersebut.
\end{abstract}

Kata Kunci: Teknologi Ameliorasi, Pemupukan, Tanah Sub-Optimal, Sifat Kimia, Pertumbuhan.

\begin{abstract}
The suboptimal land is a land that has lost its ability to support plant physiological activity. The study was to find proper auditing materials and fertilizers of soil chemicals and the growth of rice strains. The study USES experimental methods where treatment is structured in random design groups factorial patterns and repeated as much as much as 3 times. The first factor of internal amelia, biochar and pim-organic and the second dose of urea, SP36 and KCl. While study result have been derived that the organic pim watch can improve pH and growth of resistant rice while the fertilizer treatment N:P:K 225:150:150 kg ha-1 of can enhance the K-dd soil of suboptimal and that there is feedback interactions and fertilization in enhancing the P-available amount of rice.
\end{abstract}

Keywords: Restoration Technology, Fertilizing, Sub-Optimal Soil, Sifat Chemical Properties, Growth.

\section{PENDAHULUAN}

Tanah marginal ataupun sub optimal adalah tanah yang kehilangan kemampuannya untuk mendukung kegiatan fisiologis tumbuhan yangdisebabkan secara alami akibat aktivitas manusia, makadibutuhkan perlakuan lebih untuk kegiatan ekonomi (Nurmansyah, 2016). Salah satu jenis tanah sub optimal adalah tanah Ultisol yang umumnya mempunyai $\mathrm{pH}$ rendah kandungan $\mathrm{Al}$, Fe dan $\mathrm{Mn}$ terlarut yang tinggi sehingga dapat meracuni tanaman, sehingga tergolong dalam tanah dengan tingkat kesuburan rendah.

Salah satu upaya yang dapat dilakukan untuk memperbaiki sifat tanah Ultisol adalah penambahan bahan amelioran sepertipenambahan bahan organik kedalam tanah yang berperan sebagai sumber hara $\mathrm{N}$, $\mathrm{P}$, dan $\mathrm{K}$, serta mengefisienkan penggunaan pupuk anorganik (Rachman etal., 2008).

Aceh merupakan Provinsi yang sangat kaya akan keanekaragaman galur lokal padi yang perlu dimanfaatkan dan dilestarikan untuk pembangunan pertanian berkelanjutan dalam rangka meningkatkan kesejahteraan seluruh rakyat.Sumber daya genetik tersebut sangat penting untuk mendukung ketahanan pangan dan pertanian berkelanjutan (Efendi et al., 2017).Namun demikian informasi-informasi penting tersebut meluruskan teknologi budidaya padi tersebut ataupun teknologi pengelolaan tanah sawah suboptimal agar tersedia, oleh karena itu dilakukan pekerjaan penelitian berjudul "Teknologi Ameliorasi dan Pemupukan 
Tanah Suboptimal serta Hubungannya dengan Sifat Kimia Tanah dan Pertumbuhan Padi Galur Sikuneng" untuk diperoleh kondisi agronomi tanaman padi lokal tersebut serta teknologi pengelolaan tanah sawah suboptimal yang berguna dalam merakit teknik budidaya padi sawah suboptimal.

\section{METODE PENELITIAN}

Penelitian ini dilaksanakan di Rumah Kasa Fakultas Pertanian Universitas Syiah Kuala. Penelitian berlangsung selama 4 bulan, dari bulan Februari sampai bulan Mei 2019.Analisis sampel tanahdilakukan di Laboratorium Penelitian Tanah dan Tanaman Fakultas Pertanian Universitas Syiah Kuala dan Balai Pengkajian Teknologi Pertanian Aceh.

Penelitian menggunakan metode percobaan eksperimen yang dirancang dengan Rancangan yang digunakan dalam penelitian ini adalah Rancangan Acak Kelompok pola Faktorial (RAKF). Faktor pertama jenis bahan amelioran yang terdiri dari 3 taraf :Gipsum 10 ton ha ${ }^{-1}$, Biochar 10 ton ha ${ }^{-1}$, PIM-organik 10 ton ha ${ }^{-1}$ danFaktor kedua adalah pemupukan yang terdiri dari empat taraf:Tanpa Pupuk, Dosis Pupuk Urea:SP36:KCl 75:50:50 kg ha-1, Dosis Pupuk Urea:SP36:KCl 150:100:100 kg ha ${ }^{-1}$, Dosis Pupuk Urea:SP36:KCl 225:150:150 $\mathrm{kg} \mathrm{ha}^{-1}$.

\section{Analisis Data}

Dari dua faktor tersebut diperoleh 12 kombinasi perlakuan dan masing-masing perlakuan diulang tiga kali sehingga didapati 36 satuan unit percobaan.

\section{Parameter Pengamatan \\ Sifat Kimia Tanah}

Sifat kimia tanah yang diamati adalah hasil analisis sampel tanah yang dilakukan pada pertengan penelitian, terdiri atas $\mathrm{pH}, \mathrm{C}$-organik, $\mathrm{N}$-total, P-tersedia, dan Kdd, yaitu sebagai berikut:

Tabel 1. Parameter kimia tanah

\begin{tabular}{ll}
\hline Sifat Kimia & Metode \\
\hline $\mathrm{pH}$ & Elektrometik/ $\mathrm{pH}$ meter \\
$\mathrm{C}-$ Organik & Walkey and Black \\
$\mathrm{N}-$ Total & Kjeldhal \\
$\mathrm{P}-$ Tersedia & Bray II \\
Kdd & Ekstraksi $\mathrm{NH}_{4} \mathrm{OA}_{\mathrm{c}} \mathrm{pH} 7$ \\
\hline
\end{tabular}

\section{Analisis Tanah dan Pertumbuhan Akhir}

Untuk parameter pertumbuhan Yang diambil terdiri atas:

a). Tinggi Tanaman 15, 30, 45, 60, 75, 90, 105 dan 120 HST.

b). Berat Berangkasan Segar dan Berat Berangkasan Kering.

e). Jumlah Anakan Maksimum.

c). Berat Akar Segar dan Berat Akar Kering.

d). Volume Akar.

Analisis data menggunakan uji $\mathrm{F}$ dan dilanjutkan dengan Uji Beda Nyata Terkecil (BNT)pada taraf 5\%. 


\section{HASIL DAN PEMBAHASAN}

\section{Sifat Kimia Tanah}

Hasil penelitian menunjukkan bahwa rata-rata $\mathrm{pH}$ tanah berbeda nata akibat pengaruh bahan amelioran(Gambar 1a), dan berpengaruh nyata terhadap $\mathrm{pH}$ tanah sedangkan gambar 1 (b), dan rata-rata K-dd tanah berbeda nyata akibat pengaruh pemupukan N:P:K (Gambar 1b).
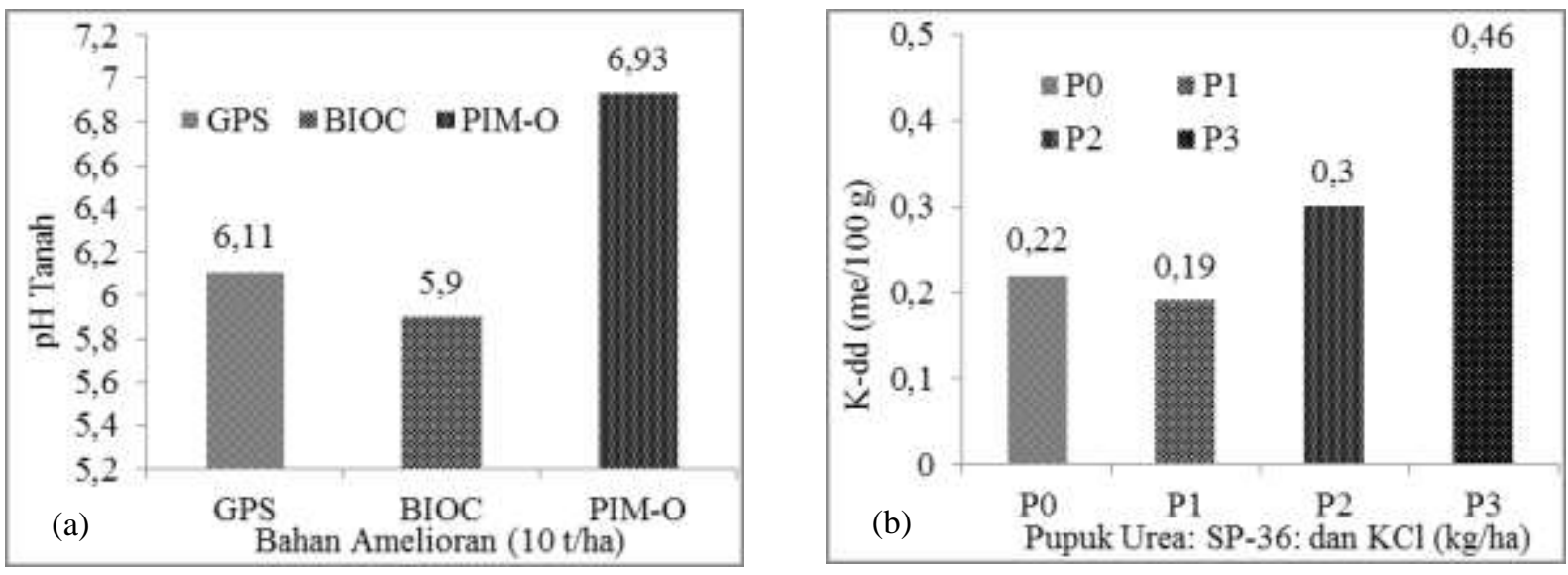

Gambar 1. (a). Rata-rata pH akibat Perlakuan bahan Amelioran, (b). Rata-rata K-dd tanah akibat Perlakuan Pemupukan

Hasil penelitian menunjukkan bahwa interaksi perlakuan bahan amelioran dan pemupukan berbagai dosis berpengaruh nyata terhadap P-tersedia tanah. Rata-rata P-tersedia tanah akibat perlakuan bahan amelioran dan pemupukan berbagai dosis dapat dilihat pada Gambar 2.

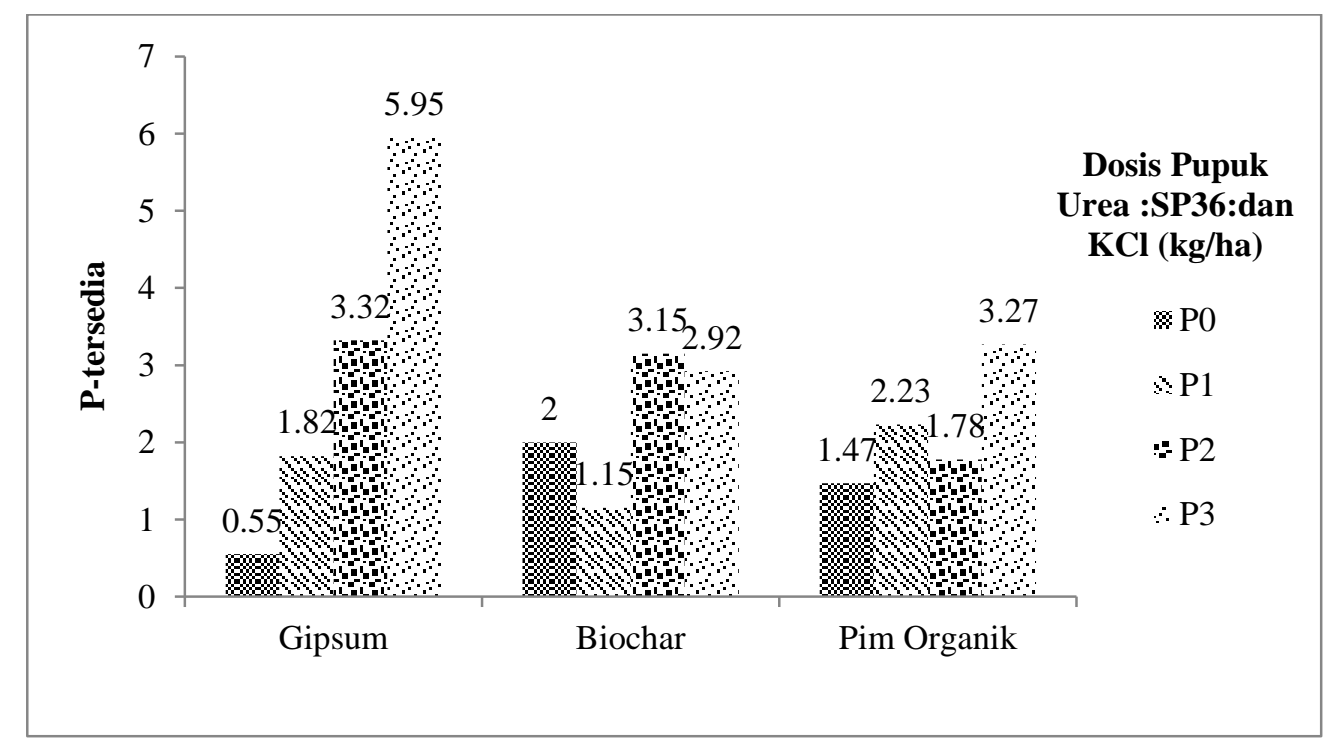

Gambar 2. Rata-rata P-tersedia akibat Perlakuan Interaksi Amelioran dan Pemupukan Berbagai Dosis

Gambar 1 (a), menunjukkan bahwa rata-rata $\mathrm{pH}$ tanah suboptimal akibat bahan amelioran yang diberikan berkisar antara 5,90 (agak asam) sampai 6,93 (netral). Nilai pH terendah dijumpai pada jenis amelioran berupa biochar dan yang tertinggi pada bahan 
amelioran PIM-organik. Reaksi $\mathrm{pH}$ tanah pada perlakuan biochar tidak berbeda nyata dengan $\mathrm{pH}$ akibat pemberian gipsum, namun berbeda nyata dengan bahan amelioran berupa PIMorganik. Bahan amelioran berupa PIM organik mampu meningkatkan $\mathrm{pH}$ tanah tertinggi $(6,93)$ termasuk dalam kategori netral. Amelioran PIM-organik mengandung C-organik yang tinggi yaitu berkisar $13,06 \%$. Bahan organik mampu meningkatkan $\mathrm{pH}$ tanah Ultisol yang agak asam $(5,67)$ menjadi netral. Bahan organik dalam dekomposisinya akan melepaskan senyawa-senyawa organik, baik itu berupa asam-asam organik ataupun kation-kation basa yang keduanya akan meningkatkan $\mathrm{pH}$ tanah. Hal ini sesuai dengan Hamed (2014) yang menyatakan kandungan unsur yang diberikan dari bahan organik dalam tanah berhubungan dengan lamanya proses mineralisasi yang dibutuhkan bahan organik untuk menyediakan hara bagi tanah. Asam-asam organik sebagai hasil dekomposisi dapat mengikat ion $\mathrm{H}^{+}$sebagai penyebab kemasaman dalam tanah sehingga $\mathrm{pH}$ tanah meningkat, asam-asam organik dapat mengikat ion $\mathrm{H}^{+}$melalui gugus karboksil yang memiliki muatan negative, naik turunnya $\mathrm{pH}$ tanah adalah fungsi ion $\mathrm{H}^{+}$dan $\mathrm{OH}^{-}$, jika konsentrasi ion $\mathrm{H}^{+}$dalam larutan tanah meningkat, maka $\mathrm{pH}$ akan menurun dan jika konsentrasi ion $\mathrm{OH}^{-}$yang dapat menetralisir aktivitas ion $\mathrm{H}^{+}$. Asam-asam organik juga akan mengikat $\mathrm{Al}^{3+}$ dan $\mathrm{Fe}^{2+}$ yang dapat membentuk senyawa komplek (khelat), sehingga $\mathrm{Al}^{3+}$ dan $\mathrm{Fe}^{2+}$ tidak terhidrolisis ulang(Bayer et al.,2001).

Gambar 1 (b), menunjukkan bahwa rata-rata K-dd akibat perlakuan pemupukan tertinggi dijumpai pada dosis pupuk tertinggi 225:150:150 kg ha-1 yaitu 0,46 me/100g yang tidak berbeda nyata dengan dosis pupuk 150:100:100 kg ha-1 tetapi berbeda nyata dengan dosis pupuk 75:50:50 $\mathrm{kg} \mathrm{ha}^{-1}$ dan 0 (tanpa pupuk). Pada analisis tanah awal hasil K-dd tanah Ultisol rendah yaitu $0,20 \mathrm{me} / 100 \mathrm{~g}$, dan dengan pemberian pupuk pada dosis tertinggi khususnya $\mathrm{K}$ dapat meningkatkan Kdd dalam tanah mencapai 0,46 me/100g yang tergolong kategori sedang. Menurut Schroeder (1974) menyatakan bahwa semakin tinggi K-dd dalam tanah, maka semakin sedikit jumlah pupuk yang perlu ditambahkan dan jika sedikit K-dd dalam tanah, maka semakin banyak jumlah pupuk yg diperlukan.

Gambar 2 menunjukkan bahwa rata-rata P-tersedia pada tanah akibat interaksi perlakuan amelioran dengan pemupukan yang tertinggi dijumpai pada perlakuan gipsum dan dosis pupuk Urea:SP36:KCl 225:150:150 kg ha-1 yaitu 5,95 ppm. Bahan amelioran berupa gipsumtidak berbeda nyata dengan bahan amelioran biochar dan bahan amelioran PIM organik tetapi nilai rata-rata tetinggi didapat oleh perlakuan gipsum, sedangkan pemupukan 225:150:150 kg ha-1 tidak berbeda nyata dengan dosis pupuk 150:100:100 kg ha-1 tetapi berbeda nyata dengan 75:50:50 $\mathrm{kg} \mathrm{ha}^{-1}$ dan 0 (tanpa pupuk). Hal ini diduga P dari pupuk SP36 yang diberikan dapat meningkatkan ketersediaan $\mathrm{P}$ dalam tanah dan kadar $\mathrm{P}$ tinggi dari sumbangan hara pupuk dan gipsum, akibatnya $\mathrm{P}$ bebas di dalam tanah karena $\mathrm{Al}$ diikat oleh khelat dan $\mathrm{pH}$ menjadi netral. Jika $\mathrm{pH}$ netral maka P-tersedia juga bebas didalam tanah. Serapan $\mathrm{P}$ yang normal akan berlangsung selama kemasaman tanah tidak terlalu tinggi. Pengikatan $\mathrm{P}$ dapat ditekan serendah-rendahnya dengan mempertahankan $\mathrm{pH}$ tanah sekitar 6 dan 7 (netral), (Supardi, 1983).Pemberian gipsum meningkatkan stabilitas tanah organik dan meningkatkan daya serap air.Menurut Sutejo et al.(2015) menyatakan bahwa gipsum mengandung kalsium yangmeningkatkan stabilitas tanah organik karena gipsum mengikat tanah bermateri organik terhadap lempung dan gipsum meningkatkan kecepatan rembesan air dikarenakan gipsum lebih menyerap banyak air.

\section{Pertumbuhan Padi Galur Sikuneng}

Hasil penelitian menunjukkan bahwa bahan amelioran berpengaruh nyata terhadap tinggi tanaman pada umur 30 HST sampai 120 HST.Rata-rata tinggi tanaman akibat bahan amelioran dapat dilihat pada Gambar 3. 


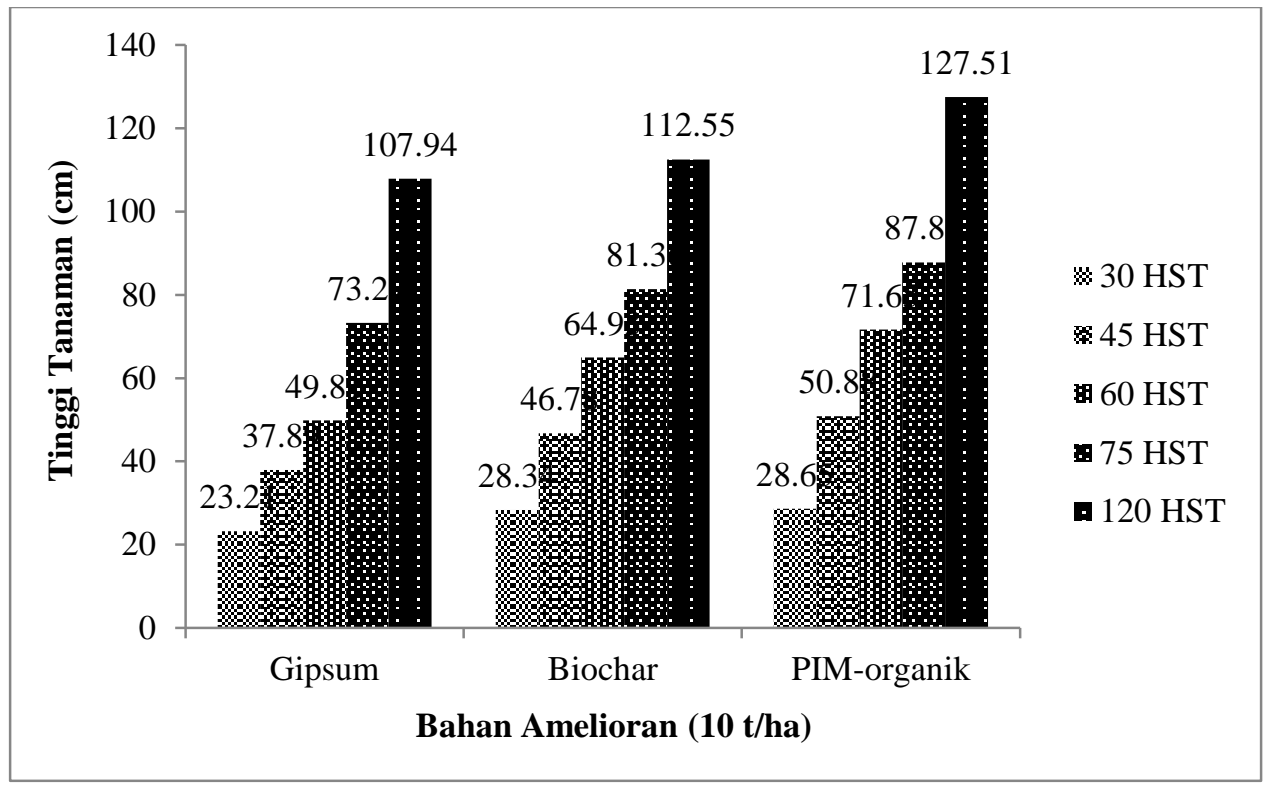

Gambar 3. Rata-rata Tinggi Tanaman akibat Perlakuan Amelioran

Hasil penelitian menunjukkan bahwa perlakuan pemupukan berbagai dosis berpengaruh nyata terhadap tinggi tanaman pada umur 75 HST sampai 120 HST. Rata-rata tinggi tanaman akibat perlakuan pemupukan berbagai dosis dapat dilihat pada Gambar 4.

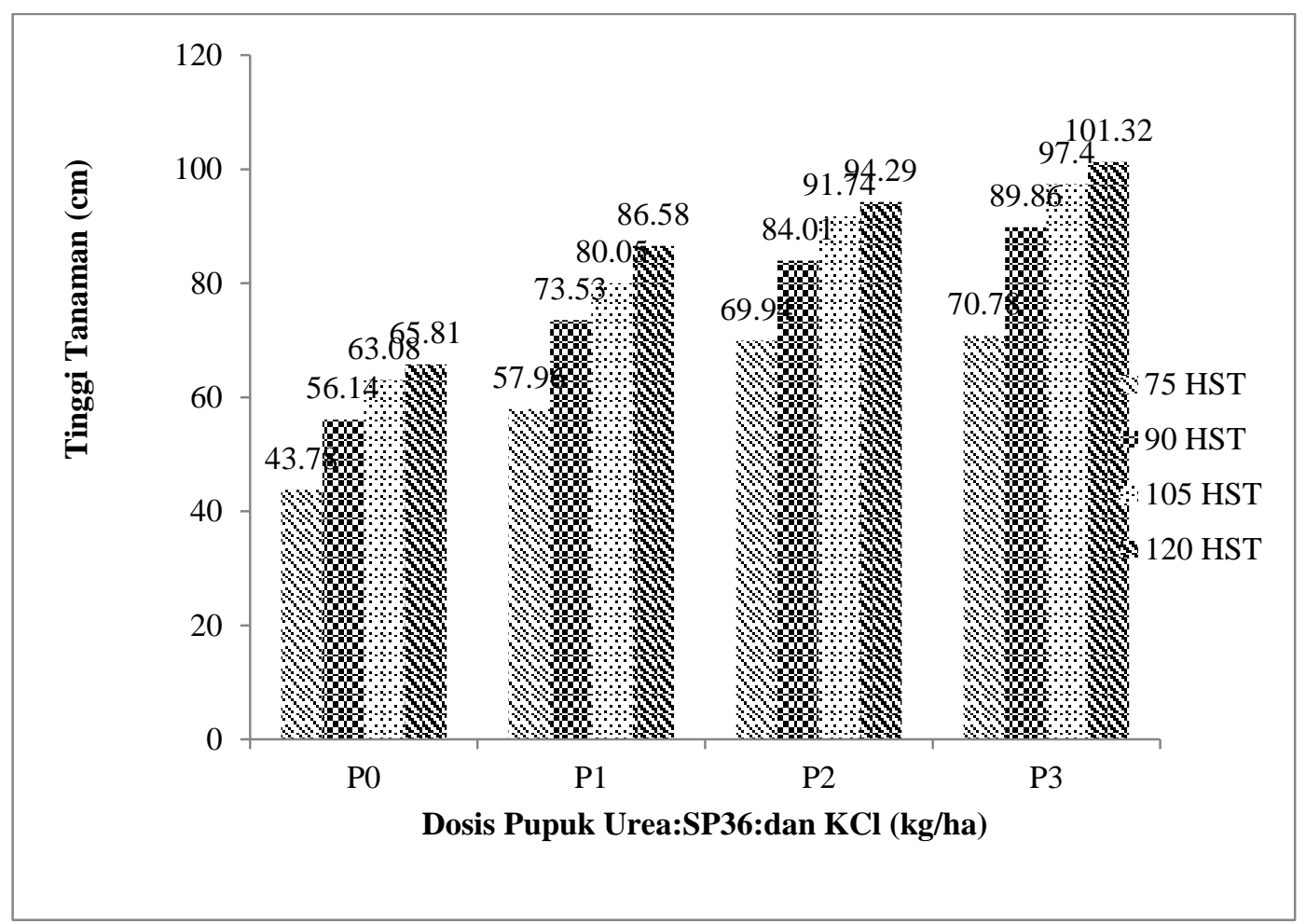

Gambar 4. Rata-rata Tinggi Tanaman akibat Perlakuan Pemupukan Berbagai Dosis 
Hasil penelitian menunjukkan bahwa perlakuan amelioran berpengaruh nyata terhadap berat berangkasan segar dan berat berangkasan kering. Rata-rata tinggi tanaman akibat perlakuan amelioran dapat dilihat pada Gambar 5.

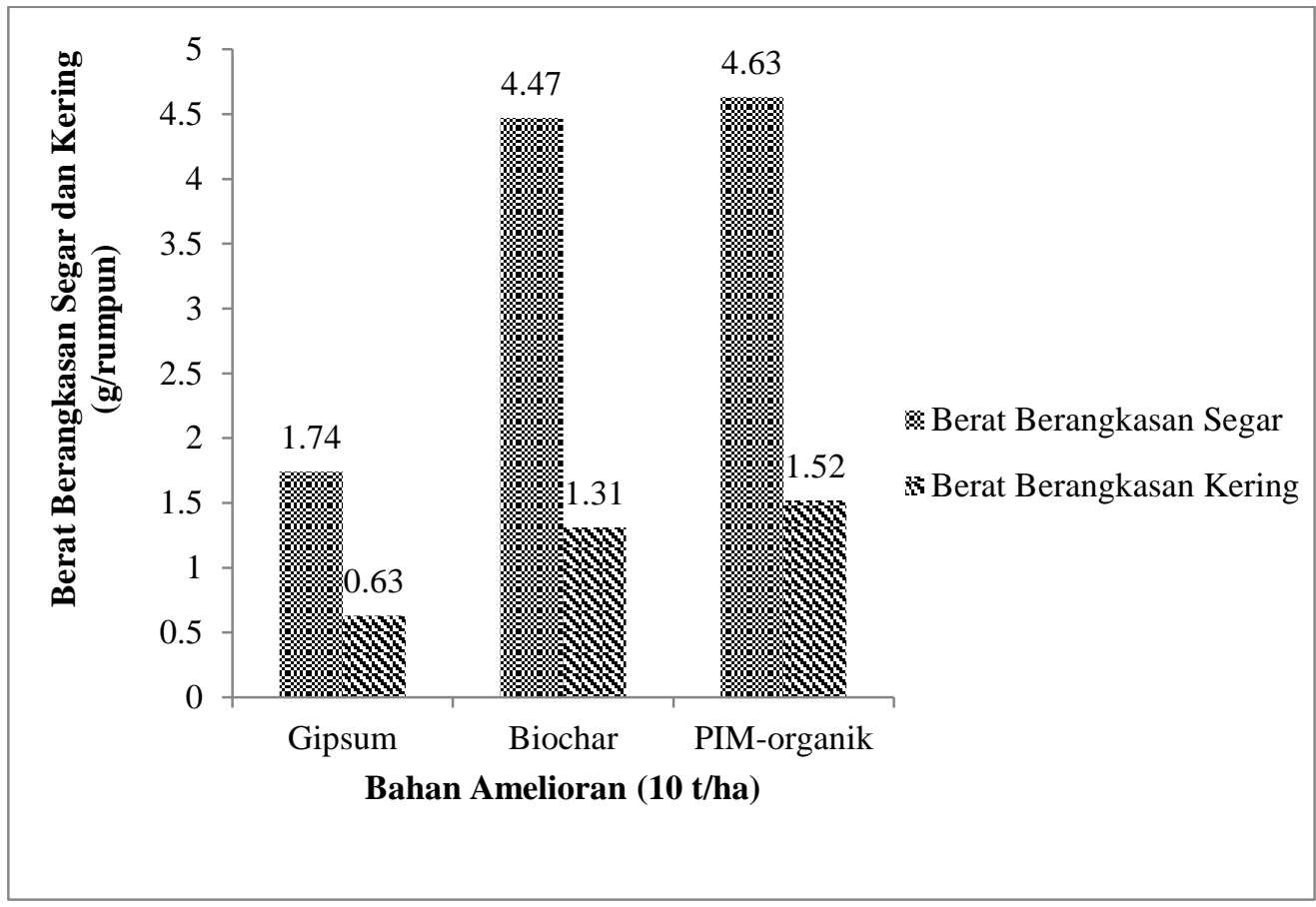

Gambar 5. Rata-rata Berat Berangkasan Segar dan Berat Berangkasan Kering akibat Bahan Amelioran

Hasil penelitian menunjukkan bahwa interaksi amelioran dan pemupukan berbagai dosis berpengaruh nyata terhadap jumlah anakan maksimum. Rata-rata jumlah anakan maksimum akibat perlakuan amelioran dan pemupukan berbagai dosis dapat dilihat pada Gambar 6.

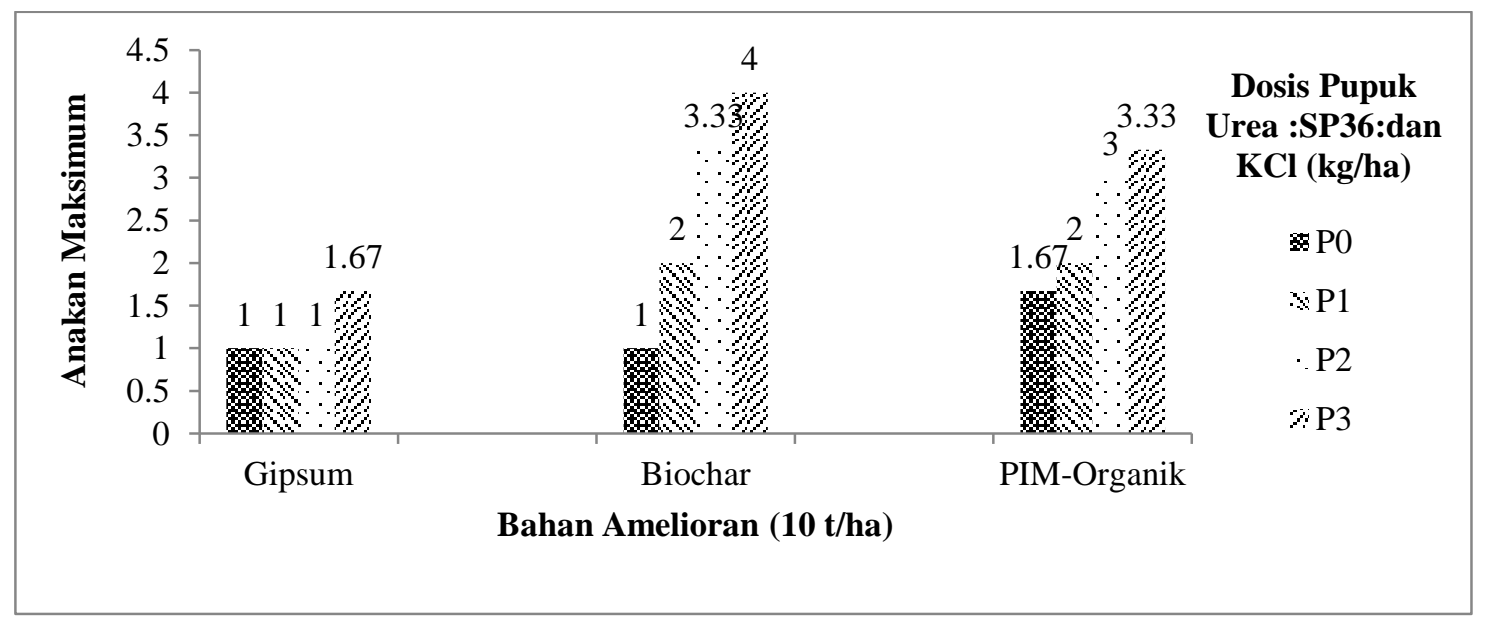

Gambar 6. Rata-rata Jumlah Anakan Maksimum akibat Interaksi Amelioran dan Pemupukan Berbagai Dosis

Gambar 3 menunjukkan perlakuan amelioran berupa PIM organik dapat meningkatkan pertumbuhan tinggi tanaman padi galur sikuneng. PIM-organik merupakan bahan organik yang memiliki kemampuan dalam membenah tanah, PIM-organik juga menambah unsur hara 
makro yang penting bagi pertumbuhan dan perkembangan tanaman. Menurut Chan et al., (2008) menyatakan bahwa aplikasi bahan organik memiliki manfaat agronomis nyata dalam meningkatkan pertumbuhan dan menurut pendapat Muchlis, (2011) bahwa keunggulan amelioran PIM organik dapat memperbaiki kualitas tanah, meningkatkan daya serap dan simpan air, mempercepat perkembangan akar serta sesuai untuk semua jenis tanah dan tanaman.PIM-organik yang sudah terdekomposisi sempurna dan melepaskan unsur hara secara bertahap karena telah dirombak terlebih dahulu oleh mikroorganisme untuk bisa menjadi bentuk senyawa-senyawa yang dapat diserap oleh tanaman.

Gambar 4 menunjukkan bahwa perlakuan pemupukan dengan berbagai dosis dapat meningkatkan pertumbuhan tinggi tanaman padi galur sikuneng. Unsur hara $\mathrm{N}, \mathrm{P}$, dan $\mathrm{K}$ yang tersedia dan pemberian pupuk tercukupi dalam jumlah yang optimal dan seimbang mampu memberikan keseimbangan hara makro bagi tanaman. Menurut Hardjowigeno (2003) unsur N dapat merangsang pertumbuhan batang, unsur $\mathrm{P}$ dapat merangsang perkembangan akar dan unsur $\mathrm{K}$ dapat membantu dalam proses pengambilan dan pengangkutan hasil fotosintesis.Menurut Jannah (2018) bahwa tanaman membutuhkan unsur hara lebih banyak pada fase vegetatif dan lebih sedikit pada masa generatif.

Gambar 5 menunjukkan bahwa nilai rata-rata berat berangkasan segar akibat perlakuan amelioran berkisar 1,74 g sampai 4,63 g, tertinggi dijumpai pada perlakuan PIM organik, PIM-organik berbeda nyata dengan biochar dan berbeda sangat nyata dengan gipsum. Hal ini diduga karena pemberian bahan organik seperti biochar dan PIM organik terpenuhi dan tersedia untuk berat berangkasan segar dan daya serap air pada tanaman padi yang intens. Air sangat berpengaruh terhadap pertumbuhan dan perkembangan tanaman. Kandungan air yang berada dalam tubuh tanaman berpengaruh terhadap hasil berat berangksansegar.Menurut Shinde dan Laware (2010), bahwa kekurangan air pada fase vegetatif dapat berpengaruh terhadap penurunan berat berangkasan segar. Gambar 5 juga menunjukkan nilai rata-rata berat berangksan kering akibat perlakuan amelioran berkisar 0,63 g sampai 1,52 g, tertinggi pada PIM organik yang tidak berbeda nyata dengan biochar tetapi berbeda nyata dengan gipsum.Hal ini disebabkan PIM-organik tercukupi dan juga terdekomposisi dengan baik sehingga memberikan unsur hara yang lengkap dalam pertumbuhan dan perkembangan tanaman padi.Kandungan unsur hara makro yang terdapat pada PIM-organik dibutuhkan dalam jumlah yang banyak oleh tanaman. $\mathrm{N}$ dan $\mathrm{Mg}$ merupakan unsur hara makro yang berpengaruh terhadap fotosintesis.Selama periode pertumbuhan, berat berangkasan kering dapat meningkat yang berasal dari hasil fisiologis tanaman (Prasad et al., 1979).

Gambar 6 menunjukkan bahwa rata-rata jumlah anakan maksimum tertinggi dijumpai pada perlakuan biochar dan perlakuan dosis pupuk 225:150:150 kg ha ${ }^{-1}$ yaitu 4,00. Hal ini diduga ketersediaan unsur kalium yang ada pada pupuk $\mathrm{KCl}$ berperan dalam peningkatan jumlah anakan. Menurut Rachman et al. (2008), penambahan bahan organik tanah dapat memberikan kontribusi terhadap ketersediaan hara $\mathrm{N}$, P, dan $\mathrm{K}$ serta mengefisiensikan penggunaan pupuk anorganik. Semakin banyak anakan yang dihasilkan, maka akan semakin meningkat volume akar yang dihasilkan. Pemberian bahan organik sebagai makanan mikroorganisme yang mengurai PIM-oganik dan biochar menjadi unsur hara seperti N, P,dan $\mathrm{K}$ yang mudah diserap oleh tanaman sehingga mempercepat pertumbuhan tanaman seperti jumlah anakan.Menurut Dobermann dan Fairhust (2002) menyatakan bahwa unsur hara N yang mudah diserap oleh tanaman mempercepat pertumbuhan tanaman seperti tinggi tanaman, jumlah anakan dan lain-lain. 


\section{KESIMPULAN DAN SARAN}

Bahan amelioran dan pemupukan dapat meningkatkan sifat kimia tanah sub optimal. Bahan amelioran $10 \mathrm{t} \mathrm{ha}^{-1}$ meningkatkan $\mathrm{pH}$ tanah berkisar0,23 sampai 1,26 point. Bahan amelioran berupa PIM-organik dapat meningkatkan $\mathrm{pH}$ tanah terbaik dibandingkan dengan bahan amelioran biochar dan gipsum. Sedangkan pemupukan N:P:K dapat meningkatkan Kdd tanah berkisar 0,20 me/100g sampai 0,46 me/100g $(10-130 \%)$. Pemupukan lebih dari Urea, SP36 dan $\mathrm{KCl}$ 150:100:100 $\mathrm{kg} \mathrm{ha}^{-1}$ yang dapat meningkatkan P-tersedia tanah dari 0,90 sampai 5,95 ppm yang disertai dengan pemberian amelioran berupa gipsum $10 \mathrm{t} \mathrm{ha}^{-1}$.

Bahan amelioran dam pemupukan N:P:K dapat meningkatkan pertumbuhan tanaman padi galur sikuneng sampai umur 75 HST, sedangkan pada umur lebih dari 75 HST pengaruh tinggi tanaman lebih didominasi akibat perlakuan pupuk N:P:K. Perlakuan amelioran berupa PIM-organik dapat meningkatkan berat berangkasan segar dan kering tanaman yang lebih tinggi dibandingkan bahan amelioran biochar dan gipsum. Jumlah anakan maksimum padi sikuneng yang dipupuk dengan N:P:Kdapat ditingkatkan jika disertai dengan bahan amelioran berupa biochar $10 \mathrm{tha}^{-1}$.

\section{DAFTAR PUSTAKA}

Bayer C, Martin-Neta LP, Mielniczuk J, Pillon CN, Sangoi L. Changes in soil organic matter fractions under subtropical o-till cropping systems. Soil Sci. Soc. Am. J. 65: 14731478.

Chan, K. Y., Van Zwieten, B. L., Meszaros, I., Downie, D., and Joseph, S. 2008. Using poultry litter Bbochars as soil amendment. Australia Journal of Soil Research.46:437-444.

Dobermann, A.And T. Fairuhust. 2002. Rice: Nutrient disorders and nutrient management. Makati : Internasional Rice Research Institude.

Efendi., Bakhtiar., Lukman H dan Sabruddin. 2017. Green rice yang berdaya hasil tinggi, hemat air dan pupuk, tahan hama dan penyakit, serta toleran cekaman kekeringan dan suhu tinggi. Fakultas Pertanian. Program Studi Agroteknologi. Universitas Syiah Kuala, Banda Aceh.

Hamed, M.H., M.A. Desoky., A.M. Ghallab., M.A. Faragallah. 2014. Effect of incubation periods and some organic materials on phosphorus forms in calcareous soils. Internasional Journal Of Technology Enhancements And Emerging Engineering Research Vol.2 (6) ; 2347-4289.

Hardjowigeno, S. 2003. Klasifikasi tanah dan pedogenesis. Akademik Pressindo.Jakarta.

Jannah, R. 2018. Pengaruh penggunaan kompos jerami padi terhadap pertumbuhan dan hasil kacang tanah (Arachis hipogeae, L).Agrotropika Hayati Vol. 5 No. 1 Februari.

Muchlis 2011.PIM-Organik. PT Pupuk Iskandar Muda, Aceh

Nurmansyah. 2016. Pengaruh jenis dan dosis amelioran terhadap pertumbuhan dan hasil padi (Oryza sativa L.) pada penanaman kedua. Skripsi. Sekolah Tinggi Ilmu Pertanian. Lampung.

Prasad, R. dan De Datta, S.K. 1979. Increasing fertilizer nitrogen efficiency in wett land rice, in nitrogen and rice. Manila: International Rice Research Institute.

Prasetyo, B. H., dan Suriadikarta, D. A. 2006. Karakteristik potensi dan teknologi pengelolaan tanah ultisol untuk pengembangan pertanian lahan kering di indonesia. Balai Besar Penelitian dan Pengembangan Sumberdaya Lahan Pertanian Dan Pengembangan 
Sumberdaya Lahan Pertanian. Balai Penelitian Tanah. Bogor. Jurnal Litbang Pertanian.

Rachman, I.A., S. Djuniwati dan K. Idris. 2008. Pengaruh bahan organik dan pupuk NPK terhadap serapan hara dan produksi jagung di inceptisol ternate. Jurnal Tanah dan Lingkungan 10:7-13.

Schroeder, E.D. 1974.Water and wastewater treatment. New York.

Shinde, BM and Laware S.1. 2010.Effect of drought stress on agronomic and micronutrients on the growth, yield of groundnut in coastal soil. J Agric Aci 2(2) : 401-402. 